\title{
EMERGING CULTURAL TOURISM PRACTICES: NEW OPPORTUNITIES FOR SMALL CITIES?
}

\author{
Greg Richards \\ Professor of Placemaking and Events at Breda University of Applied Sciences and Professor \\ of Leisure Studies at Tilburg University in the Netherlands; richards.g@buas.nl
}

DOI: 10.15170/TVT.2021.06.04.01

\begin{abstract}
How will cultural tourism develop in the post-pandemic world? In order to look forward, this paper first looks back at the historical development of cultural tourism, from the rarified world of high culture to the mass consumption of pre-covid 'overtourism'. This also mirrors a growing debate about the function of cultural tourism in cities, from a 'good' form of tourism to attract high-spending visitors to problems of overcrowding, commodification and gentrification. Linked to these changes are shifts in cultural tourism practices, the rise of new cultural tourism destinations and modes of travel. We consider the rise of creative clusters and event programs as examples of emerging new practices in cultural tourism, highlighting the role of major events such as the European Capital of Culture. The focus of such major event programmes has progressively shifted to smaller cities, including Pécs in Hungary. How have these changes affected the places that cultural tourists visit, and what are the prospects for cultural tourism in the future?
\end{abstract}

Keywords: Cultural tourism, cultural heritage, urban tourism, European Capital of Culture, creative districts, social practices

\begin{abstract}
Absztrakt
Hogyan fog fejlődni a kulturális turizmus a pandémiát követő világban? Az elöretekintés érdekében jelen tanulmány elöször is visszatekintést nyújt a kulturális turizmus történelmi fejlődése kapcsán, a túlzottan kifinomult magas kultúra világától a Covid 19 előtti “túlzott turizmus" tömeges fogyasztásáig. Az elméleti bevezető egyúttal a városi kulturális turizmus funkciójáról szóló, egyre növekvő vitát is tükrözi, amely a nagy összegeket elköltő látogatók vonzására irányuló turizmus "jó" formájától, a túlzsúfoltság, az árucikké válás és a dzsentrifikáció problémáiig terjed. Ezekhez a változásokhoz kapcsolódnak a kulturális turizmus gyakorlatában bekövetkezett módosulások is, vagyis az új kulturális turisztikai célpontok és utazási módok megjelenése. A kreatív klaszterek és a rendezvényprogramok felemelkedését a kulturális turizmusban kialakuló új gyakorlatok példáinak tekintjük, kiemelve az olyan nagyszabású események szerepét, mint az Európa Kulturális Fővárosa program. Az ilyen nagyszabású rendezvényprogramok fókusza fokozatosan áthelyeződött a kisebb városokra, köztük a magyarországi Pécsre. Hogyan befolyásolták ezek a változások a kulturális turisták által felkeresett helyeket, és milyen jövőbeli kilátásokkal bír a kulturális turizmus?
\end{abstract}

Kulcsszavak: kulturális turizmus, kulturális örökség, városi turizmus, Európa Kulturális Fövárosa, kreatív városrészek, szociális gyakorlatok 


\section{The development of cultural tourism}

In recent decades the field of cultural tourism has developed rapidly. The recognition of cultural tourism as a separate field of tourism activity only arrived in the 1980s (RICHARDS 1996), but since then the cultural tourism market has grown substantially in terms of volume and complexity. As explained by Pier Luigi Sacco, (SACCO - FERILLI - TAVANO BLESSI 2018), culture has undergone significant changes in the modern era. In the original 'Culture 1.0 ' configuration, culture was patronized by rich individuals and industrialists, who laid the foundation for the contemporary system of museums. This was linked to a classic concept of 'high culture', in which the highlights of European culture were presented to people as a lesson in the importance of civilization and the fine arts.

The echoes of the Grand Tour remained the leading element of cultural tourism until the 1980s. At this stage, the de-industrialisation of the developed economies of Western Europe and North America led to a new role for culture as an economic engine (Culture 2.0). Culture was employed as a regeneration strategy, in which tourism played an increasingly important role as an economic stimulus and a means of improving the image of declining regions. The economic development role of cultural tourism remained paramount until new technologies provided the basis for consumers to become directly involved in the cultural production process. In Culture 3.0 Internet and social media allowed people to create their own cultural experiences, undermining the role of museums as 'factories of meaning' and producing a dialogue between cultural producers and consumers about the direction of cultural development.

The current emergence of Culture 4.0 sees integration of consumption and production becoming even more developed, with the advent of 'hybrid culture', representing a mix of different cultural origins and interpretations, but also combining live and virtual expressions of culture. This hybridization of culture has become even more evident following the Covid-19 Pandemic, which encouraged people to produce and consume culture online. In Culture 4.0, the rationale for value creation also changes. Instead of relying on the protection of ideas and concepts of intellectual property, the advent of new media means that value is created precisely through the sharing of ideas and concepts. This is one of the reasons why co-creation has become a central tool in the development of tourism experiences.

These developments in cultural production and consumption have been paralleled by a number of 'turns' in the academic analysis of culture and tourism (Figure 1). As RICHARDS (2021) describes, the initial analysis of cultural tourism in the 1980s was linked to the 'cultural turn', which highlighted the growing importance of culture in society. The growth of mass tourism in the 1980s and 1990s was seen as one marker of the 'mobilities turn', highlighted by authors such as John Urry. As physical mobility on the developed economies grew, cultural tourism became an increasingly important area of consumption, and the observation of tourists as actors on the stages provided by cultural attractions and events provided material for the 'performative turn', marked by the publication of Tim Edensor's 'Tourists at the Taj' (2008). The subsequent growth of the creative economy provided the basis for a further 'creative turn', in which tourists became not just actors but also active producers of creative experiences (RICHARDS 2011). Most recently, we can observe a 'curatorial turn', which has been necessitated by the flood of cultural and creative experiences made available to tourists, most notably through new media and Internet platforms. The act of curation helps tourists choose from among the flood of possibilities, removing the choice stress that increasingly confronts consumers. We are now guided by curated lists, such as Time Out's 'coolest neighbourhoods in the world'. 
Figure 1: Development of culture and analytical 'turns'

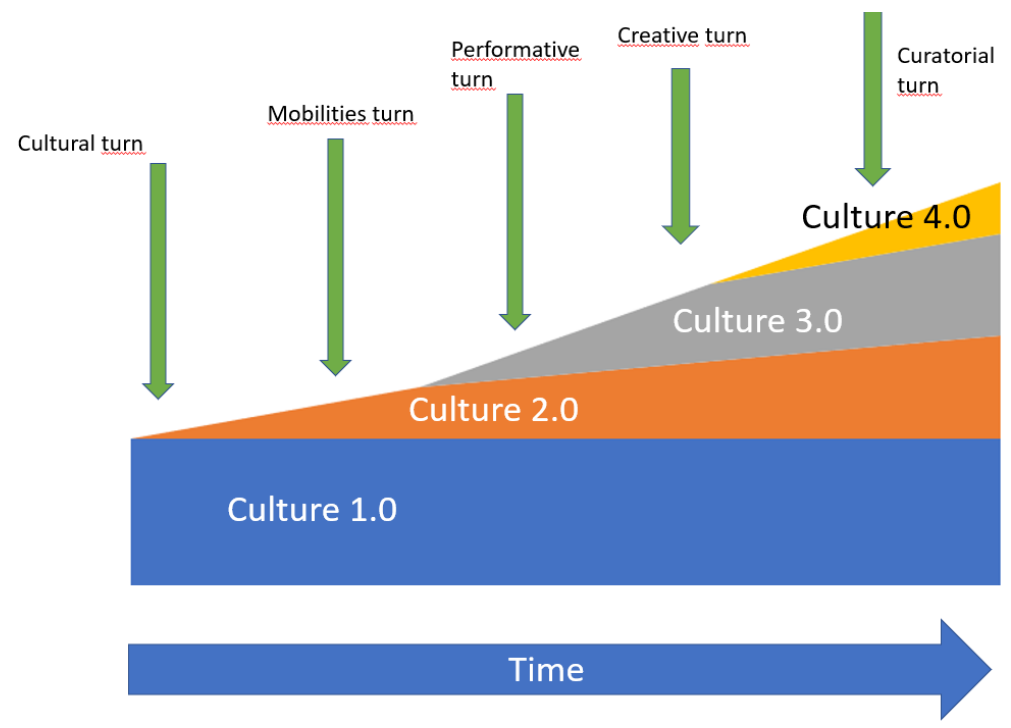

Source: Edited by the author

The development of cultural tourism over recent decades has therefore been marked by substantial increases in volume, linked to qualitative shifts in the objects and motivations of cultural tourists. Cultural tourists now motivated by popular as well as high culture, intangible as well as tangible culture, and they are increasingly likely to be found in previously untouristed areas, for example in the suburbs of cities (MAITLAND - NEWMAN 2014). These changes underline the need to not only study the actors in the cultural tourism system, but also the contexts in which cultural tourism takes place and the practices that actors undertake in these different contexts.

As BARGEMAN and RICHARDS (2020) argued, cultural tourism can be seen as a form of ritual, in which a series of practices are developed by tourists and tourism producers in a range of different contexts (Figure 2). These rituals, following the analysis of RANDALL COLLINS (2004), are based on the physical co-presence of actors who have a shared focus of attention in the case of cultural tourism some form of tangible or intangible culture. The ritual generates 'emotional energy' for the participants, which encourages them to repeat the experience. This creates what Collins terms an 'Interaction Ritual Chain', in which participants move from one ritual to another, seeking to increase their return in terms of emotional energy. This is a powerful explanation for repeated visits to cultural attractions by tourists, as well as their tendency to flock together in the same places. This ritual behaviour not only gives a return to individuals in the form of emotional energy, but also builds symbols of collective identity which affect the contexts in which cultural tourism takes place (see Figure 2). In the case of Pécs, for example, the designation of UNESCO World Heritage or the European Capital of Culture programme provided new contexts to develop cultural tourism, which in turn has an important impact on the behaviour of cultural tourists. 
Figure 2: A model of cultural tourism practices

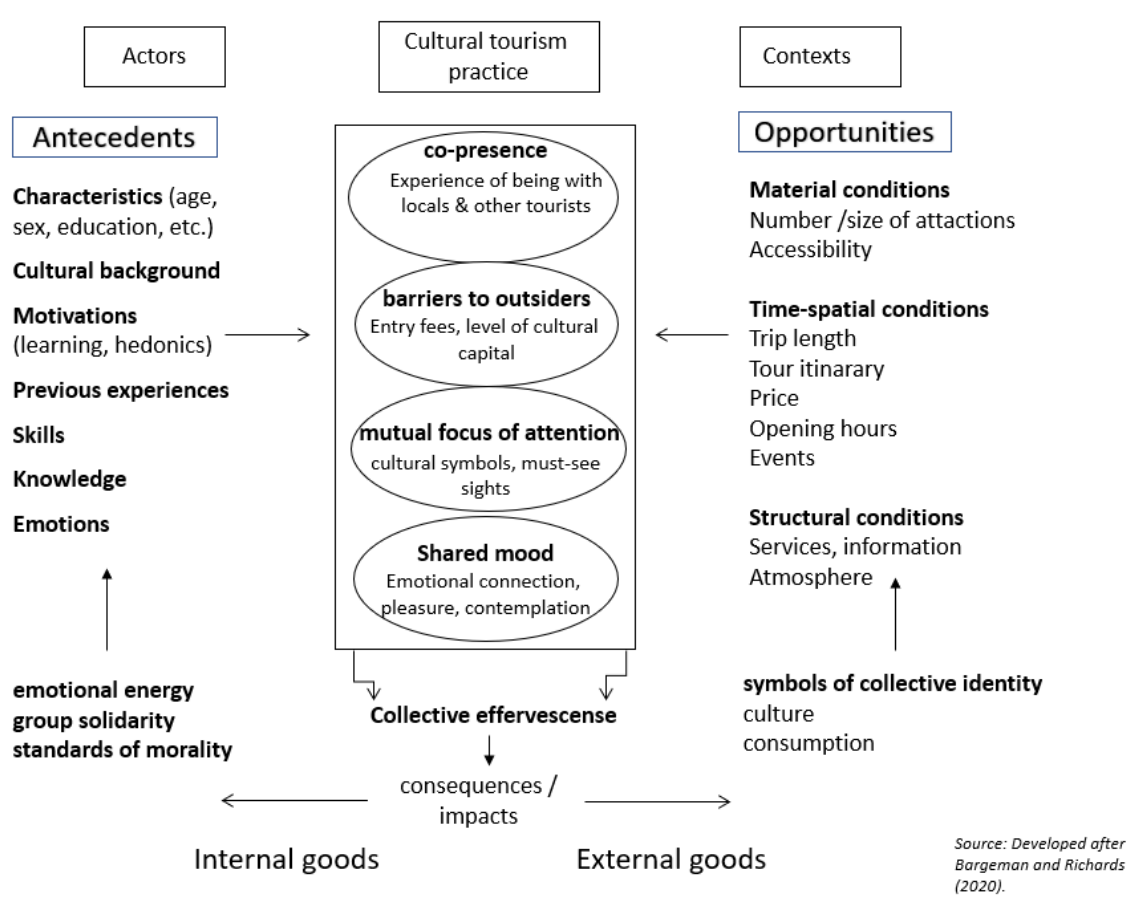

Source: Edited by the author

An important implication of a practice model of cultural tourism is that the previous division of actors into producers and consumers is replaced by a more integrated vision, which implies a process of co-creation between tourists and tourism suppliers (RICHARDS 2021). The range of actors involved in tourism is also expanding, thanks to the technological possibilities provided by Culture 4.0. These days, we can all produce stories about tourism experiences through social media platforms like TripAdvisor, which then affect the experiences and motivations of others. The provision of experiences has also moved beyond the formal tourism sector and out into the community as a whole, thanks to systems such as Airbnb. These days, local residents are not just observers of tourism, but they also have a role as makers of tourism experiences. The increased interest that tourists show in the daily life of locals also means that unwilling and unwitting locals are being sucked into the tourism production and consumption system.

This in turn means that more areas of cities become tourist destinations, and tourists and locals are increasingly in contact with one another. This spillover of tourism from the exclusive leisure spaces of tourism consumption to the realm of everyday life is an important reason for growing tensions between locals and tourists, and discussions about 'overtourism'. These tensions are particularly evident in major tourist destinations that offer clusters of attractions for cultural tourists, such as Barcelona, Venice or Amsterdam. In this sense, cultural tourism has ceased to be seen as a purely 'good' form of tourism (RICHARDS 2001), bringing in wealthy and welleducated visitors, to a 'bad' type of tourism that causes overcrowding in city centres, and which displaced local residents through processes of 'touristification'. The turning point was evident in Barcelona in 2012, when for the first time attitudes towards tourism began to exhibit negative tendencies (RICHARDS 2015). This also reflects a growing integration between tourism and other urban functions, which mean that tourists are another major group in the city that competes for public space, amenities and cultural facilities. 


\section{New cultural tourism practices}

The combination of more actors entering the tourism system, and a greater range of contexts being used for cultural tourism experiences, means that many new cultural tourism practices are emerging. Cities such as Pécs not only have their traditional cultural tourism highlights such as the Cathedral or Szechenyi Ter, but now the city also boasts a range of more informal experiences, often based on intangible culture. Examples include a growing range of craft beer breweries and bars, food trucks and shops selling craft and creative products. Such eclectic mixes of cultural and creative experiences have been labelled as 'new urban tourism' (ROCHE 1992), which is based on a series of practices that usually feed on contemporary culture and everyday life in the destination.

The increasing integration of everyday life and (cultural) tourism poses a number of opportunities and challenges for places. On the one hand this has enabled tourism to expand, for example by colonizing the living spaces of the local community, through collaborative economy systems such as Airbnb. On the other hand, there are growing challenges for the cultural sector to extract economic value from cultural tourism, because for example, tourists may simply stroll around the neighbourhoods of the city without paying entry fees or even buying food and drink. In some cases, the avoidance of paying has become a kind of sport, collectively engaged in by tourists, sometimes with the help of locals and tourism suppliers (SU et al. 2021). This underlines that the development of cultural tourism is no longer a tourism issue, but a community issue.

New urban tourism can effectively be generated through the creation of new contexts in which cultural tourism can take place. These include most notably the building of new museums, cultural districts and the organization of events. This is evident from the proliferation of new museums globally, including the new Guggenheim in Abu Dhabi, the expansion of the Hermitage and MOCO franchises to Barcelona and also the opening of boutique museums, such as MONA in Hobart, Tasmania. The focus of these new museums is different from their predecessors, particularly in terms of a narrative based not on the classic canons of national history or schools of art, but on surprising, delighting or challenging audiences. This again underlines the growing power of curators, who can tell a story through gathering artworks not previously thought of as belonging together.

Creative districts have also become a weapon in the global struggle for distinction. In the book Creative Districts Around the World (MARQUES - RICHARDS 2014) we charted the rise of the creative district format in many different countries. Interestingly, three of the case studies contributed to the book came from Hungary, including the Zsolnay Cultural Quarter in Pécs. Originally the development of creative quarters was a strategy employed at local level to support the creative industries and attract tourists. But in recent years these policies have also been taken up at national level, such as China's development of cultural districts. As the OECD (2014) noted, large cultural districts in Beijing, Shanghai, and other large Chinese cities now attract millions of visitors a year. There are plans for the number of districts to be expanded still further. We see, therefore, a form of 'serial reproduction' (RICHARDS - WILSON 2006) emerging, in which cities copy successful formats from one another, helped by a system of 'policy tourism' (GONZALEZ 2011). It becomes increasingly hard to develop distinctive cities, particularly for tourism, since many of the main attractions are serially reproduced.

As RICHARDS and PALMER (2010) have noted, the search for distinction means that the contemporary city has to 'become eventful, or die'. Events have been increasingly used as a policy tool by cities to underpin culture-led development, to create a distinctive image, or to foster social cohesion. In particular, events linked to international brands, such as the European 
Capital of Culture (ECOC), or the World Design Capital, have become desirable for their ability to deliver increased tourism and visibility for cities. As these events rotate, there is also an interesting exchange between the global event and the local context of the host city. These systems of rotating events feed a bidding system that increases the competition between cities, but which also raises the profile of the event itself, which is useful for the organizing body as well as the host cities. This was clearly the case in Hungary with the competition for the 2010 ECOC. In total, seven Hungarian cities made it through to the second phase of the selection competition, including Pécs. The large number of cities competing made it inevitable that some very small places were vying for this European title, reflecting a long-term trend of declining host city population in the competition. The average population for the host cities has fallen from around one million in the first five years of the competition (1985-1989), compared with 160,000 for the host cities in 2022 and 2023. The next Hungarian host city, Veszprém, has a population of only 56,000 .

Figure 3: The population of ECOC host cities between 1985 and 1989 and 2022 and 2023

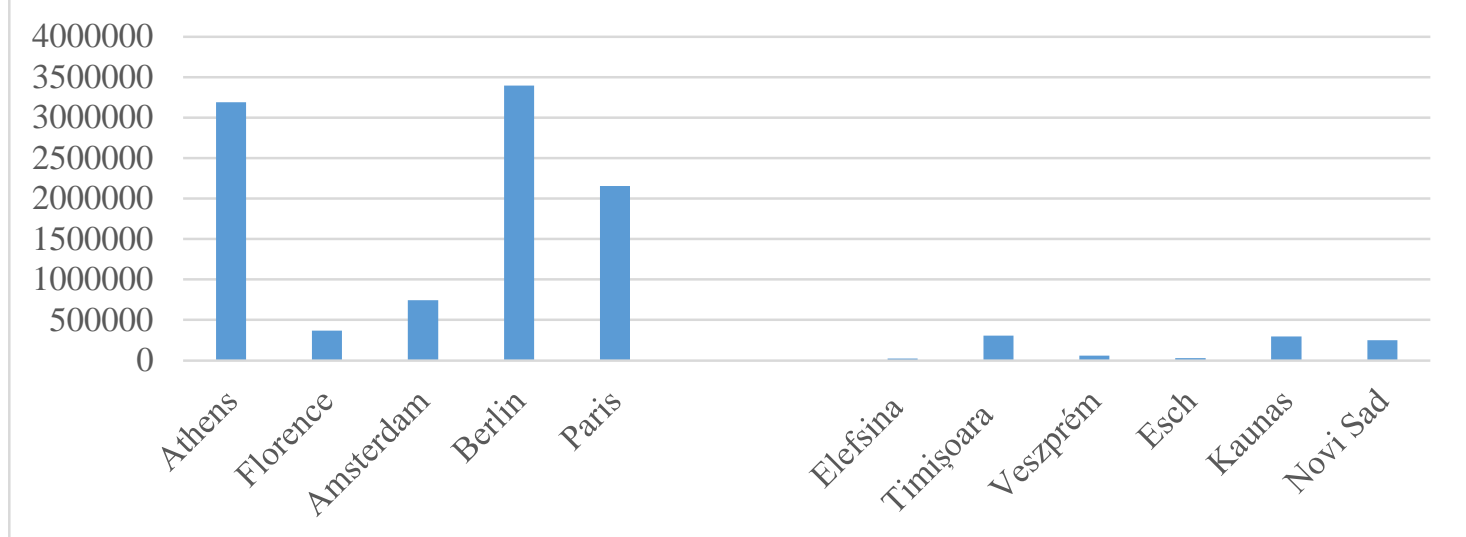

Source: Edited by the author

The shrinking size of the cities involved in the ECOC programme implies a number of changes in the way in which the event is used by cities. Firstly, the main priority for 'small cities with big dreams' (RICHARDS - DUIF 2019) is to put themselves on the map. External projection and attracting tourists therefore becomes a more important priority than social cohesion, for example. Secondly, the small size of the host city makes links to the surrounding region even more important. This can provide the potential for collaboration that draws in more resources than those available to the city itself, as well as being a potential source of audiences for the programme (Luxemburg and Greater Region 2008). Thirdly, the development of new cultural facilities became even more central to the ECOC project, because small cities are often lacking in cultural infrastructure. These trends can be observed in the case of Pécs, which used the ECOC in 2010 to develop the Zsolnay Cultural Quarter, build the South-Transdanubian Regional Library and Knowledge Centre, and renovate the Kodály Centre as well as many public spaces.

As expressed in the Pécs bidbook, "....the task for Pécs is to work out how new life can be breathed into old and empty industrial facilities or entire factories by establishing centres of cultural and artistic activity; how to boost the night economy of the centre, how to make the everyday life of the city more interesting by transforming the environment in an artistic manner". In other words, Pécs had to first be transformed in to a 'cultural city' to become worthy of the title. 
CSAPÓ, PINTÉR, and AUBERT (2016) listed the many improvements made in the city:

To effectively manage the high quality events which were planned on that occasion, many old facilities had to be replaced with new projects. Included amongst them were the construction of one of the most modern conference centres and concert halls in Europe $\left(15,000 \mathrm{~m}^{2}\right)$; the South Trans-Danubian Regional Library and Knowledge Centre $\left(9000 \mathrm{~m}^{2}\right)$; a large exhibition space; the then abandoned, partly ruined Zsolnay factory was turned into the "Zsolnay Cultural Quarter". The cultural district (including 22,000 $\mathrm{m}^{2}$ of buildings and a 15,000 $\mathrm{m} 2$ public park) provides a variety of cultural functions, and also hosts the University's Faculty of Arts, in the backdrop of modern and traditional architectures. As part of the investment of the ECoC project, 70 urban public spaces and parks were renovated, making up an area of approximately 583,000 $\mathrm{m}^{2}$.

The ECOC had significant impacts on cultural tourism. Firstly, the new attractions served to increase the number of tourists, but also to change their flow through the city. As GUERREIRO and MENDES (2014) demonstrated, the main tourist attractions before the ECOC were concentrated in the centre of Pécs. During the ECOC, tourists began to visit other sites spread throughout the city, including the Zsolnay Cultural Quarter, the university and the TV tower. The growing number of cultural tourists also stimulated a significant growth in bedspaces in the city, particularly in the years after 2010 (Figure 4). Having seen the success of the ECOC in generating tourism, investors decided that Pécs was a good bet for tourism after all. As in many other ECOC cities, the rush to invest actually came after the event, not before it. This is because in spite of the successful history of the ECOC in most cities, the locals don't tend to believe the tourists will come until they have seen them with their own eyes.

Figure 4: Change in bedspaces in Pécs, 2007-2013

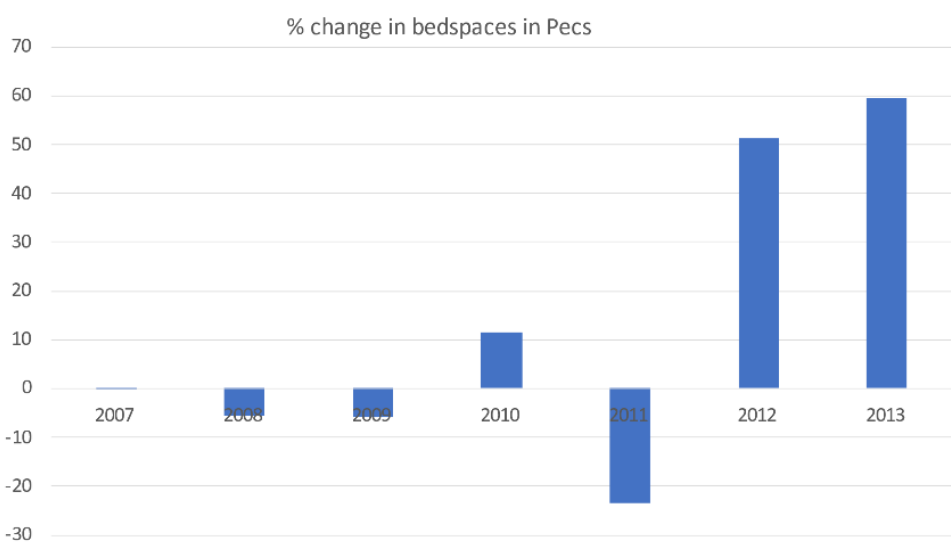

Source: Edited by the author

The Ex-post evaluation of Pécs programme underlined the role of new renovated spaces in attracting tourists and residents. Research also indicated that the Hungarian image of Pécs as a cultural city improved significantly ECoC. Before the ECOC Pécs was rated as a cultural city by only $35 \%$ of the population, compared to $56 \%$ by the end of 2010 . Over two-thirds of local respondents had a positive attitude to the ECOC programme in 2010, compared to only $35 \%$ a few years previously.

Another city that staged a successful ECOC, but where hotel investment was also late in coming, was Sibiu in Romania. Sibiu staged the event in 2007, and saw the development of 
cultural tourism as a central thrust of the programme. As in Pécs, Sibiu used the title to regenerate the fabric of the city, with new attractions and renovated buildings in the old city. The number of tourists staying in Sibiu increased dramatically in 2007, and also grew over the longer term. The growth was particularly significant for foreign tourists (Figure 5). As in Pécs, the number of tourists visiting the previously untouristed areas of the city increased.

Figure 5: Sibiu foreign tourist overnights, 2007-2013

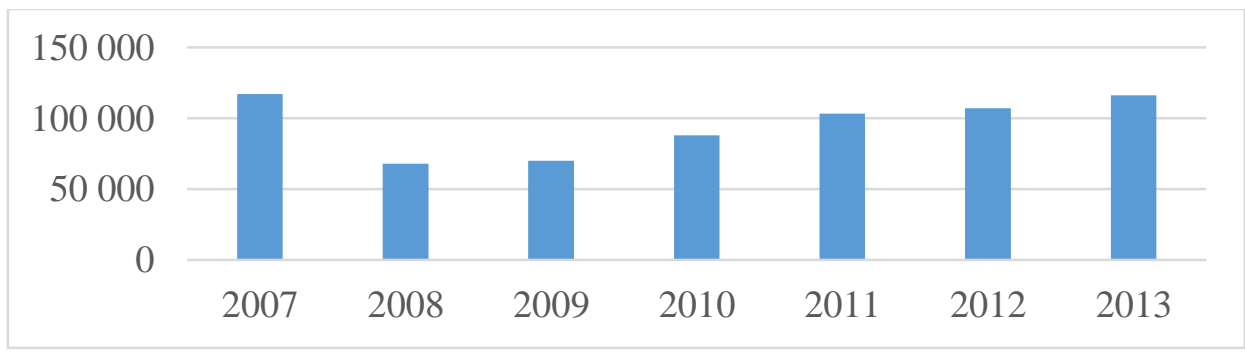

Source: Edited by the author

The long-term boost in cultural tourism was helped by the surprise factor of a little-known city in Eastern Europe having the title, which generated considerable press coverage. The longitudinal monitoring of the event (RICHARDS - ROTARIU 2016) showed that residents of the city felt that there had been benefits in terms of economic, cultural, social and quality of life aspects. Although the appreciation of benefits fell slightly after 2007, over the longer term this increased again, showing that the effects of the ECOC were long-lasting and sustainable (Figure $6)$.

Figure 6: Effects of the ECOC in Sibiu as perceived by residents (2007-2013, \% agree)

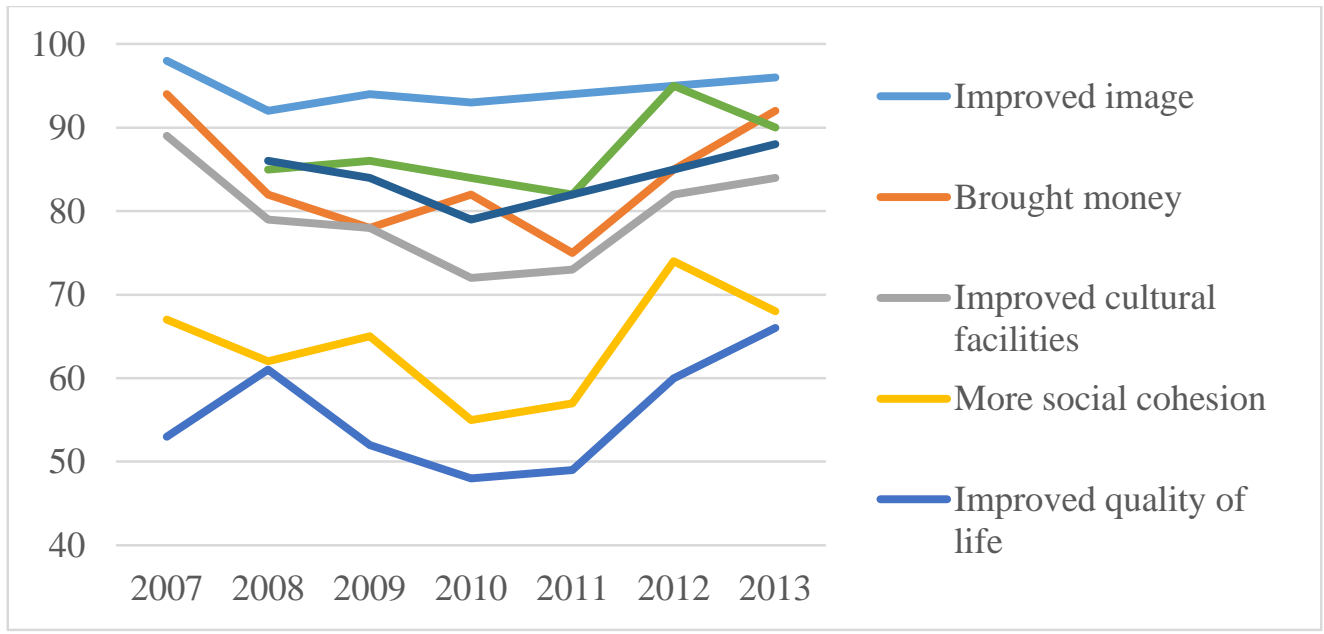

Source: Edited by the author

\section{Critical success factors for small cities with big dreams}

Comparing the experiences of Sibiu and Pécs, both smaller cities in the East of Europe, one can see a lot of parallels. Both cities gained considerable benefits from the ECOC title, and in particular the development of new forms of cultural tourism. As CSAPÓ et al. (2016) noted, this success was due to a wide range of actors:

Collective efforts of the local community representing the people from different institutions (administration, culture, education and education), enforced by the success European Capital 
of Culture 2010 helps to introduce a plenty of services for the tourists and local citizens in the area of culture.

This collective effort helped to increase the cultural attractiveness of the city and to attract more cultural tourists. Particularly in the case of Sibiu, this produced a dramatic increase in tourism spending. The analysis of the experience of small cities like Sibiu and Pécs indicates that there are a number of key success factors involved in such programmes (RICHARDS - DUIF 2019):

- Political Will, Vision and Consistency

- Building Relationships and Forging Collaboration

- The Small City Needs a Story

- Risk-taking

- Knowing What to Measure

- Using the Underdog Position

- Embedding and Support

- Holistic Approach

- Ensuring a Legacy

The political will was probably the factor that set Pécs apart in the competition for the ECOC title. The Mayor put together a close-knit team who produced a convincing story about WHY the city should be a cultural capital - in contrast to the other bidding cities, who simply thought they deserved the title because they had culture. According to KOLTAI (2013) the author of Pécs' bid József Takács described it as "a convincing fiction, sort of putting the ways and depth of implementation into the hands of the citizens of Pécs." This 'fiction' turned out to be an engaging piece of stortytelling, which convinced the ECOC jury that Pécs had a real purpose in bidding for the title. Pécs also used the underdog position well, because it was up against the firm favourite Budapest, which also seemed to be the Government's choice. The bid showed that the city had a holistic approach to cultural development, rather than emphasizing a single aspect of culture. Most importantly, the bid book argued that the ECOC would leave a significant legacy, and that has certainly proved to be the case.

Pécs also illustrates the power of developing new tourism practices, which bringing together actors and contexts in meaningful rituals. Like many other cities Pécs is now full of new cultural tourism practices, from craft beer to food trucks and creative tourism. Pécs has transformed itself in two short decades from a city celebrating the opening of its first McDonald's into a diverse and rich arena for 'new urban tourism', which can act as an example for other small cities with big dreams.

\section{The future relationship between culture and tourism in cities}

Although the Covid Pandemic brought an abrupt halt to the dizzying growth of cultural tourism in cities worldwide, there are already signs in some places that old patterns of mass cultural tourism are beginning to re-establish themselves. In major cities such as Barcelona this is already evident in the queues outside designer stores in the Passeig de Gràcia and low-end retailers like Primark. Unless cities begin to respond proactively, we could soon see the old problems emerge.

As suggested by our report for the United Cities and Local Governments before Covid (RICHARDS - MARQUES 2018), the increasing complexity of urban systems means that an integrated approach to urban governance is needed, including more integrated policies for culture and tourism. The rise of new urban tourism and the collaborative economy means that will be increasingly difficult to separate locals and tourists or their use of different areas of the 
city, for example. The rise of Airbnb and other collaborative economy platforms is not just a tourism issue, but an issue of housing policy and spatial planning. This is now being recognized in cities such as Barcelona and Amsterdam in the new measures they are taking to curtail the activities of Airbnb. In Amsterdam registration of Airbnb properties is now compulsory, and Airbnb has agreed to collaborate in the policing of rentals. The effect has apparently been dramatic, with a reduction of the number of Airbnb listings to around a quarter of their previous levels by October 2021.

We have yet to see what effect such measures will have in the post-covid tourist city. But it unlikely that a reduction in Airbnb listings will dampen the tourist thirst for the 'local' (RUSSO - RICHARDS 2016). In fact, the post-pandemic city will probably see new forms of collaboration between tourism actors emerging through the facilitation of technology platforms. One sign of this is the rise in curation, which helps reduce the choice stress of tourists presented with a growing array of cultural opportunities (RICHARDS 2021). The new curators of cultural tourism help to identify those areas of the city, and those experiences, which are worthy of attention. Companies such as Time Out now provide not just information on attractions and events, but also curated lists of 'The World's Coolest Neighbourhoods'. The curators identify the up and coming areas of the city, the places with future value. This enables the cultural tourist to collect cool experiences, without having to queue at the museum.

The advent of the tourism curator in another sign that the tourism system is increasingly about more than tourism, and that other sectors are also increasingly dealing with tourism as well. The growing range of actors involved in the co-creation of tourism means that collaboration is essential, making the move towards the 'collaborative city' or the 'sharing city' all the more likely. In the future we will have to re-draw our conceptual map of the (cultural) tourist city as a more integrated and collaborative organism (Figure 7).

Figure 7: The evolution of the tourist city

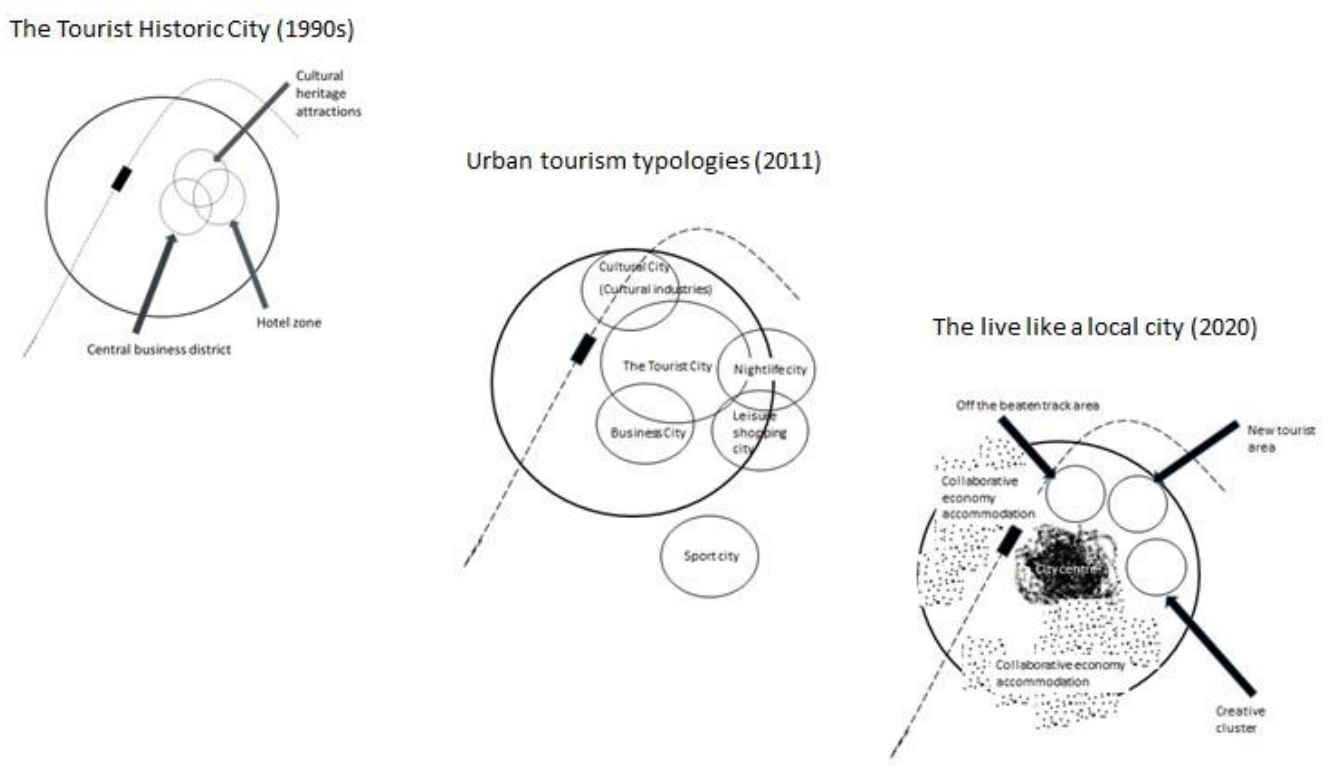

Source: RICHARDS 2022

In the past it was reasonably easy to identify the tourist areas of the city. Particularly small historic cities, such as Pécs, had limited flows of cultural and business tourism to the city centre, which housed the main cultural attractions (ASHWORTH - TUNBRIDGE 2000). Rapid urban 
development in recent decades has produced a more varied and diverse pattern of land use, and produced a number of clusters related to leisure and tourism (ASHWORTH - PAGE 2011). As consumption functions moved back into city centres, they became increasingly cool places to live, work and visit. Cities also stimulated the growth of cultural and leisure zones as a means of increasing economic activity, including the extension of the night time economy. Increasingly, however, tourism is no longer restricted to these enclaves, but has spread through the urban fabric as a whole, supported by facilities such as Airbnb. The 'live like a local' city (RICHARDS 2022) is likely to become an important platform for cultural tourism in future, particularly as traditional cultural tourism is supplemented by more visitors looking for the ‘extraordinary everyday’ (RICHARDS - MARQUES 2018).

\section{Acknowledgement}

This paper is based on a keynote presentation to the 4th International Tourism Marketing Conference organized by The Institute of Marketing and Tourism of the Faculty of Economics of the University of Pécs, Hungary, $5^{\text {th }}$ November 2021.

\section{Biosketch}

Greg Richards is Professor of Placemaking and Events at Breda University of Applied Sciences and Professor of Leisure Studies at Tilburg University in the Netherlands. His recent publications include Rethinking Cultural Tourism (EDWARD ELGAR 2021) and Small Cities with Big Dreams (ROUTLEDGE 2019).

\section{References}

ASHWORTH, G. J. - PAGE, S. J. (2011): Urban tourism research: Recent progress and current paradoxes. Tourism Management, 32(1), 1-15.

ASHWORTH, G. J. - TUNBRIDGE, J. E. (2000): The tourist-historic city. London: Routledge.

BARGEMAN, B. - RICHARDS, G. (2020): The practices of leisure: a new approach to understanding participation. Annals of Tourism Research, 84. https://doi.org/10.1016/j.annals.2020.102988.

COLLINS, R. (2014): Interaction Ritual Chains. Princeton University Press.

CSAPÓ, J. - PINTÉR, R. - AUBERT, A. (2016): Chances for tourism development and function change in the rural settlements with brown fields of Hungary. E-review of Tourism Research, 2.

GONZÁLEZ, S. (2011): Bilbao and Barcelona 'in motion'. How urban regeneration 'models' travel and mutate in the global flows of policy tourism. Urban studies, 48(7), 1397-1418.

GUERREIRO, M. - MENDES, J. (2014): Experiencing the Tourist City. The European Capital of Culture in Re-designing City Routes. Journal of Spatial and Organizational Dynamics, 2(4), 288-306.

KOLTAI, Z. (2013): The Time Of Returning Optimism. An Ex-Post Evaluation Of The" European Capital Of Culture-Pécs 2010" Programme. Acta Geographica Universitatis Comenianae, 57(2), 151-163. 
LUXEMBURG AND GREATER REGION (2008): Luxemburg and greater region, cultural capital of Europe 2007.

MAITLAND, R. - NEWMAN, P. (Eds.) (2014): World tourism cities: Developing tourism off the beaten track. Routledge.

MARQUES, L. - RICHARDS, G. (2014): Creative Districts Around The World. http://creativedistricts.imem.nl/

OECD (2014): Tourism and the Creative Economy. Paris: OECD.

RICHARDS, G. (1996): Cultural Tourism in Europe. Wallingford: CABI.

RICHARDS, G. (2011): Creativity and tourism: The state of the art. Annals of Tourism Research, 38(4), 1225-1253.

RICHARDS, G. (2015): Barcelona: A victim of its own success? In Hodes, S. (ed.) Amsterdam: Anticipating the Future, pp. 58-59.

RICHARDS, G. (2021): Rethinking Cultural Tourism. Cheltenham: Edward Elgar.

RICHARDS, G. (2022): Urban tourism as a special type of cultural tourism. In van der Borg, J. (ed.) Research Agenda for Urban Tourism. Cheltenham: Edward Elgar.

RICHARDS, G. (2022): Urban tourism as a special type of cultural tourism. In van der Borg, J. (ed.) Research Agenda for Urban Tourism. Cheltenham: Edward Elgar.

RICHARDS, G. - DUIF, L. (2018): Small Cities with Big Dreams: Creative Placemaking and Branding Strategies. New York: Routledge.

RICHARDS, G. - PALMER, R. (2010): Eventful Cities: Cultural Management and Urban Revitalisation. Routledge: London.

RICHARDS, G. - ROTARIU, I. (2015): Developing the Eventful City in Sibiu, Romania. International Journal of Tourism Cities, 1(2), 89 - 102.

RICHARDS, G. - WILSON, J. (2006): Developing creativity in tourist experiences: A solution to the serial reproduction of culture? Tourism Management 27, 1209-1223.

ROCHE, M. (1992): Mega-events and micro-modernization: on the sociology of the new urban tourism. British Journal of Sociology, 563-600.

RUSSO, A.P. - RICHARDS, G. (2016): Reinventing the Local in Tourism: Producing, Consuming and Negotiating Place. Bristol: Channel View Publications.

SACCO, P. L. - FERILLI, G. - TAVANO BLESSI, G. (2018): From culture 1.0 to culture 3.0: Three socio-technical regimes of social and economic value creation through culture, and their impact on European Cohesion Policies. Sustainability, 10(11), 3923.

SU, M. M. - YU, J. - QIN, Y. - WALL, G. - ZHU, Y. (2021): Ancient town tourism and the community supported entrance fee avoidance-Xitang Ancient Town of China. Journal of Tourism and Cultural Change, 1-23. 